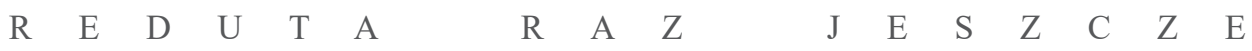

PAMIĘTNIK TEATRALNY 2020/2 (274)

ISSN 0031-0522, e-ISSN 2658-2899

INSTYTUT SZTUKI PAN

DOI: $10.36744 /$ pt.233

Jagoda Hernik Spalińska

Instytut Sztuki PAN

ORCID: 0000-0002-7813-3212

\title{
OSTERWA NA FRONCIE
}

Osterwa at the Front

(c) $(7)(9)$ 


\begin{abstract}
Abstrakt: Tekst dotyczy lat 1919-1920, czasu odzyskania przez Polskę niepodległości i wojny polsko-bolszewickiej, który z przyczyn cenzuralnych był skrótowo omawiany w literaturze poświęconej Juliuszowi Osterwie i Reducie, chociaż zarówno Osterwa, jak i jego zespół byli w tę wojnę zaangażowani. Autorka próbuje odtworzyć warunki społeczno-polityczne, w jakich twórca Reduty otwierał teatr w 1919. Skupia się na tym, jak stan wojny ze wszystkimi sąsiadami Polski wpływał na dyskusje na temat zadań teatru. Opisuje również związki intelektualne Osterwy ze Stefanem Żeromskim i Wincentym Lutosławskim, którzy pozostawali wówczas w orbicie myśli Romana Dmowskiego, ideologa Narodowej Demokracji. Na tej podstawie stawia tezę, że w latach 1919-1920 myślenie Osterwy o scenie narodowej i powinnościach „,nowoczesnego Polaka” było bliskie endeckim ideom, Reduta zaś - w pierwszych miesiącach swej działalności - była dla środowisk prawicowych nadzieją na odnowienie polskiego teatru.
\end{abstract}

Słowa kluczowe: Juliusz Osterwa, Reduta, Roman Dmowski, Narodowa Demokracja, wojna polsko-bolszewicka, Stefan Żeromski

\begin{abstract}
The article concerns the years 1919 and 1920, the time of Poland's newly regained independence and the Polish-Bolshevik war. Due to censorship, this period used to be mentioned only briefly in literature on Juliusz Osterwa and the Reduta theatre even though the director and his ensemble were involved in this war. The author attempts to reconstruct the socio-political conditions in which the founder of Reduta opened his theatre in 1919. She focuses on how Poland's being at war with all its neighbours had an influence on the discussions about the tasks of the theatre. She also describes Osterwa's intellectual engagements with Stefan Żeromski and Wincenty Lutosławski, who at the time were close to the philosophy of Roman Dmowski, the ideologist of National Democracy. Based on these facts, she argues that between 1919 and 1920 Osterwa's thinking about national theatre and the duties of the "modern Pole" was akin to ND ideals, and that in the first months of Reduta's activity, right-wing circles saw it as a chance for the renewal of Polish theatre. (Transl. Z. Ziemann)
\end{abstract}

Keywords: Juliusz Osterwa, Reduta, Roman Dmowski, National Democracy, Polish-Soviet War, Stefan Żeromski 
Zzkic ten dotyczy wybranych aspektów historii Reduty w okresie wojny polsko-bolszewickiej, w której teatr Juliusza Osterwy, założony kilka miesięcy wcześniej, brał udział prawdopodobnie jako teatr frontowy ${ }^{1}$. Uwagę zwraca fakt, że zespół Osterwy jako jedyny w Warszawie przerwał występy w stolicy w okresie nasilenia walk na froncie polsko-bolszewickim i nie tylko w czasie bitwy warszawskiej, ale przez cały miesiąc, między 6 sierpnia a 5 września, nie grał w swej siedzibie. Sam Osterwa wspominał ten okres zdawkowo ${ }^{2}$. Aktorzy Reduty zmobilizowani do armii polskiej grali natomiast w przedstawieniach dla żołnierzy dawanych w koszarach i szpitalach, niektórzy występowali nawet w zespołach frontowych organizowanych właśnie przez Osterwę z ramienia ZASP-u w ramach Centralnego Komitetu Propagandy Związków Artystycznych ${ }^{3}$. Niewiele wiemy o tej jego działalności, niewiele wiemy również o teatrach żołnierskich z czasu Wielkiej Wojny i późniejszych walk o niepodległość Polski. Temat został zaledwie wstępnie rozpoznany przez Marię Wosiek $^{4}$ i Stanisława Piekarskiego ${ }^{5}$. Piekarski o Reducie nie wspomina w ogóle, Wosiek natomiast, opisując ówczesne poczynania Osterwy, odwołała się do ustaleń Szczublewskiego. Jednak w kronice życia Osterwy, wydanej w 1971, Szczublewski nie mógł nawet napomknąć, z kim Polacy walczyli w 19206. Gdy w 1989 zniknęły przeszkody cenzuralne, nikt tego wątku nie podjął, a Reduta była rozpatrywana niemal wyłącznie jako przedsięwzięcie estetyczne lub ezoteryczne ${ }^{7}$. Tymczasem miała przecież rodowód ideowy i działała w poczuciu misji społecznej.

${ }^{1}$ Zob. J. Szczublewski, Żywot Osterwy, Warszawa 1971, s. 167. Działalność teatrów na froncie polsko-bolszewickim omówiona jest w książce S. Piekarskiego Polskie teatry żotnierskie 1915-1939, Warszawa 1999, jednak dotyczy ona placówek organizowanych przez wojsko. Występy zawodowych aktorów są uwzględnione tylko w przypadku czterech zespołów działających w ramach „czołówek artystycznych", nie ma wśród nich Reduty.

2 „Podczas wakacji zaszedł wypadek najścia bolszewików. Reduta w całości poszła na front. Zaś redutówki utworzyły ognisko dla żołnierzy pod nazwą Reduta na ulicy, zdaje się, Jasnej. Na szczęście ta nawała nie trwała długo, choć była groźna" - pisał Osterwa w 1924, cyt. za: J. Szczublewski, Pierwsza Reduta Osterwy, Warszawa 1965, s. 285.

3 J. Szczublewski, Żywot..., op. cit., s. 167-169; M. Wosiek, Polskie teatry wojskowe 1915-1922, „Pamiętnik Teatralny” 1980 z. 1, s. 110-111.

${ }^{4}$ Ibidem.

5 S. Piekarski, op. cit.

${ }^{6}$ We fragmencie o zaangażowaniu Osterwy mowa jest tylko o enigmatycznej wojnie, zob. J. Szczublewski, Żywot..., op. cit., s. 167-169.

7 Zob. Z. Osiński, Pamięć Reduty. Osterwa, Limanowski, Grotowski, Gdańsk 2003. 
Tytuł Osterwa na froncie ma więc szersze znaczenie: interesuje mnie „front” ideologiczny, na którym Osterwa ze swoim zespołem stał w tamtym czasie, a także „front”, na którym został w pewnym sensie ustawiony przez badaczy. Innymi słowy, szkic stanowi próbę kontynuacji dyskusji o ideologii politycznej Reduty, rozpoczętej przez Rafała Węgrzyniaka ${ }^{8}$. Poszukiwałam odpowiedzi na pytania: dlaczego akurat Osterwa czuł się zobowiązany do tego, by w roku 1920 stanąc na czele teatrów frontowych, a aktorzy z jego zespołu studyjnego wzięli czynny udział $\mathrm{w}$ obronie ojczyzny, narażając życie jak żołnierze? Z czego to wynikło i jak do tego doszło? Proponuję spojrzeć na początki działalności Reduty i życie teatralne Warszawy po odzyskaniu niepodległości z perspektywy ignorowanego zazwyczaj w badaniach Stanisława Pieńkowskiego, recenzenta teatralnego organu Narodowej Demokracji, czyli „Gazety Warszawskiej”. Wpływ tego dziennika na przekonania polityczne Osterwy mógł być istotny, a nie był dotąd analizowany ${ }^{9}$. Jak się wydaje, w pierwszych miesiącach po odzyskaniu niepodległości, gdy nie było jeszcze jasne, która $\mathrm{z}$ frakcji politycznych zdominuje ośrodki władzy w Polsce, Osterwa pozostawał pod wpływem ideologii narodowej w większym stopniu niż później, gdy zbliżył się do obozu piłsudczykowskiego, z którym współpraca dawała zespołowi określone korzyści, by nie powiedzieć, że w ogóle możliwość istnienia. Warto te ideowe filiacje prześledzić, ponieważ ich wpływ widać w wielu późniejszych działaniach Osterwy, a także - w formie bardziej ukrytej - w osobistych zapiskach artysty.

\section{WIZJA TEATRU NOWOCZESNEGO W FORMIE, NARODOWEGO W TREŚCI}

Stanisław Pieńkowski (1872-1944) ${ }^{10}$, pochodzący z Siedlec krytyk literacki i teatralny, publicysta, thumacz i poeta, związał się z Warszawą już w okresie gimnazjalnym. Podczas studiów za udział manifestacji, tzw. kilińszczyźnie, zorganizowanej

\footnotetext{
${ }^{8}$ R. Węgrzyniak, „Ideologia polityczna Reduty”, wystąpienie na seminarium „Reduta. Nowe Fragmenty”, IS PAN 28 XI 2019. Węgrzyniak sytuował jednak poglądy polityczne Osterwy bliżej obozu piłsudczykowskiego.

9 Agnieszka Marszałek opisuje Stanisława Pieńkowskiego jako jednego z recenzentów teatralnych, którzy chętnie krytykowali ten zespół. Zaczyna jednak swój opis nie od początku istnienia zespołu i od recenzji inauguracyjnej prapremiery Ponad śnieg, lecz od recenzji styczniowego przedstawienia, w której Pieńkowski opisuje dublurę Mieczysława Szpakiewicza w roli Wiko, granego wcześniej przez Osterwę. Od tego mniej więcej czasu rozpoczyna się rozczarowanie Pieńkowskiego: w jego przekonaniu Osterwa bowiem grał Wiko zbyt „miękko”, w odróżnieniu od Szpakiewicza, który jako gorszy aktor wykorzystywał mocniejsze środki. W tym też okresie Reduta powoli oddala się od kręgu Narodowej Demokracji, by zbliżyć się do kręgów piłsudczykowskich, które - jak powoli stawało się jasne - będą sprawować władzę w Polsce. Por. A. Marszałek, Zła prasa Reduty, [w:] Reducie na stulecie. Studia i rozpoznania, red. D. Kosiński, W. Świątkowska, Warszawa 2019, s. 365-377.

${ }_{10}$ Zob. A. Hutnikiewicz, hasło „Pieńkowski Stanisław”, [w:] Polski Słownik Biograficzny, t. XXVI, Kraków 1981, s. 125-127.
} 
przez Ligę Narodową 17 kwietnia 1894 w rocznicę insurekcji warszawskiej, został aresztowany i uwięziony, a później zmuszony do opuszczenia zaboru rosyjskiego. Zamieszkał w Krakowie, gdzie podjął współpracę z czasopismem ,Życie”. Publikował własne wiersze, przekłady Verlaine’a, był jednym z pierwszych polskich tłumaczy dzieł Friedricha Nietzschego (Tak mówił Zaratustra w 1901) ${ }^{11}$. Zajmował się krytyką literacką, interesował się malarstwem i architekturą, a także kulturą i filozofią hinduską - przekładał hymny Rigwedy. Podczas pierwszej wojny światowej, w latach 1917-1918, znalazł się w Kijowie i jako współpracownik Stanisławy Wysockiej w Teatrze Studya był świadkiem poczynań Osterwy.

W 1918 wrócił do Warszawy, gdzie zaczął pisać recenzje teatralne i komentować życie artystyczne w prasie endeckiej. Współpracował między innymi z „Gazetą Poranną”, „Rzeczpospolitą”, „Słowem Polskim”, „Myślą Narodową,, „Gazetą Warszawską". Za młodu Pieńkowski uważał się za socjalistę, lecz jeszcze w okresie studenckim związał się ze Związkiem Młodzieży Polskiej „Zet” i Ligą Narodową. Tej opcji politycznej pozostawał wierny przez cały okres międzywojenny i z tych pozycji ideologicznych komentował i recenzował polskie życie teatralne, posuwając się czasem do stwierdzeń rasistowskich.

Gdy Polska odzyskiwała niepodległość w 1919, najważniejszym i najbardziej nowoczesnym teatrem w Warszawie był Teatr Polski Arnolda Szyfmana. W charakterze dramaturga, pełniącego w zasadzie funkcję kierownika literackiego, pracował tam Leon Schiller. Pieńkowski na łamach „Gazety Warszawskiej”, wyrażając poglądy Narodowej Demokracji i osób do tej formacji zbliżonych, odnoszące się do polskiej racji stanu, krytykował dyrekcję teatrów Polskiego i Małego. Stwierdzał stanowczo, że repertuar tej najlepszej w Polsce sceny rozczarowuje, nie odpowiada bowiem deklaracji Schillera, że jednym z celów Teatru Polskiego jest „przygotowanie podłoża dla rozwoju odrębnego stylu sztuki narodowej”. Jak pisał dalej Pieńkowski: „każdy z nas miał prawo oczekiwać od dyrekcji tego, co nazywam linią repertuaru"12. Tymczasem plan repertuarowy ukazał się dopiero w wyniku wymiany listów, do jakiej doszło między dyrekcją Teatru Polskiego a Pieńkowskim ${ }^{13}$. Program Schillera zawierał wiele pozycji, od krotochwili Oj, mężczyźni, mężczyźni Zalewskiego do Wyzwolenia Wyspiańskiego. Według Pieńkowskiego trudno to nazwać linią repertuarową.

${ }^{11}$ Thumaczenie Tak mówit Zaratustra (1901) przygotował z pierwszą żoną, Marią Cumft-Pieńkowską, ibidem. Zob. też S. Pieńkowski, Dusza thumu i inne wiersze, wstęp i oprac. M. Urbanowski, Kraków 2005.

${ }_{12}$ S. Pieńkowski, Wieczory teatralne. O linię repertuaru, „Gazeta Warszawska” 1919 nr 93 (4 IV) https://crispa.uw.edu.pl/object/files/146310/display/Default [dostęp: 22 VI 2020].

${ }^{13}$ Spisem, o którym wspomina Pieńkowski, nie dysponujemy. Wiadomo, że w lipcu 1918 Leon Schiller odbył „w Skolimowie długą konferencję z Arnoldem Szyfmanem na temat przyszłej współpracy” i wręczył mu ,projekt repertuaru Teatru Polskiego na kilka lat (kilkadziesiąt sztuk)”, Mała kronika życia i twórczości Leona Schillera 1887-1924, [w:] L. Schiller, Na progu nowego teatru 1908-1924, oprac. J. Timoszewicz, Warszawa 1978, s. 15. 
Sposób, w jaki Pieńkowski postrzegał Teatr Polski, pokazuje jego opis premiery w tym teatrze w listopadzie 1919, na kilka dni przed otwarciem Teatru Reduta. Premierę Twarzy i maski Luigiego Chiarellego komentował następująco:

[komedia] jakiegoś autora włoskiego, bardzo mierna i ordynarna. Dziwne, że taką rzecz tłumaczył p. W.[łodzimierz] Perzyński. O wiele mniej dziwne, że to Teatr Polski wystawił: przywykliśmy już do wszelkiej na tej scenie tandety. Maską dyrekcji tego teatru była jej szumna autoreklama o tworzeniu „teatru narodowego, o którym mówił Mickiewicz, śnił Słowacki itd.”, zaś jej twarzą jest to, co już blisko od roku widzimy jako regułę na tej zasobnej scenie. Od czasu do czasu wdziewa się maskę w postaci tego lub owego patetycznego wyskoku repertuarowego, ale poziom repertuaru (jego etos) jest tak mizerny, że nie przynosi zaszczytu rozległej wiedzy literackiej, jaką się p. Leon Schiller de Schildenfeld „dramaturg” Teatru Polskiego popisywał. „Po owocach ich poznacie je”, a wśród tych owoców prócz stałej tandety są też wykrzykniki snobizmu teatralnego, którymi się hipnotyzuje tłum inteligencji oraz „czynniki miarodajne” (czytaj - ,złotodajne”). Zupełny brak idei teatralnej i jaskrawy brak repertuaru - oto zasadnicza cecha Teatru Polskiego. A jednocześnie dużo hałasu i gestów reklamowych ${ }^{14}$.

Pieńkowski nie tylko nie ukrywał krytycznego stosunku do Teatru Polskiego i jego kierownictwa, ale też doprowadził do otwartego konfliktu, który znalazł finał w sądzie ${ }^{15}$. Krytyka Pieńkowskiego - głos pewnego środowiska - nie była pozbawiona uprzedzeń rasowych ${ }^{16}$, ale nie na nich polegała. Chodziło przede wszystkim o repertuar - nie dość przemyślany jak na placówkę, która miała wychować nowoczesny naród ${ }^{17}$. Kolejne recenzje przybrały już formę jawnych, niepozbawionych niewybrednych aluzji, ataków z jasno określonymi zarzutami o brak idei i niewłaściwy repertuar:

Czwartkowa premiera - komedia Molnara Oficer gwardii w dalszym ciągu stwierdza literackie upodobania dyrekcji teatrów Polskiego i Małego oraz jej niewysoki poziom artystyczny. [...] Stale karmi się publiczność marnymi utworami literatur obcych, żadną wytyczną teatralną niepowiązanymi. [...] Po co marnować czas i talenty artystów na takich, jak ów Oficer gwardii, mizeriach pseudo-psychologicznych i naturalistycznych, gdy jednocześnie biada się w dyskusjach, że teatry nasze znajdują się w upadku i dzwoni się na alarm w szumnych artykułach? Skąd ten stały rozdźwięk między słowem a czynem? Czyżby to była planowa akcja w kierunku obniże-

14 S. Pieńkowski, Piśmiennictwo i sztuka. Teatr Polski, „Gazeta Warszawska” 1919 nr 320 (23 XI), https://crispa.uw.edu.pl/object/files/146095/display/Default [dostęp: 22 VI 2020].

15 Zob. też E. Krasiński, Arnold Szyfman. Portret dyrektora w labiryncie teatru, Warszawa 2013.

${ }^{16}$ Pojawiło się nawet sformułowanie, że Żyd nie będzie uczył Polaka polskości, jak również o „rasowej obcości dyrekcji Teatru Polskiego” (por. przypis 12).

${ }^{17}$ Od czasu konfliktu z dyrekcją Teatru Polskiego Pieńkowski zapisywał nazwę tej placówki zawsze w cudzysłowie jako teatr „Polski”, a nazwisko Szyfmana zawsze jako „pan Schifman”. Nazwisko Leona Schillera zaś było obowiązkowo podawane w swym pełnym brzmieniu, czyli Leon Schiller de Schildenfeld. 


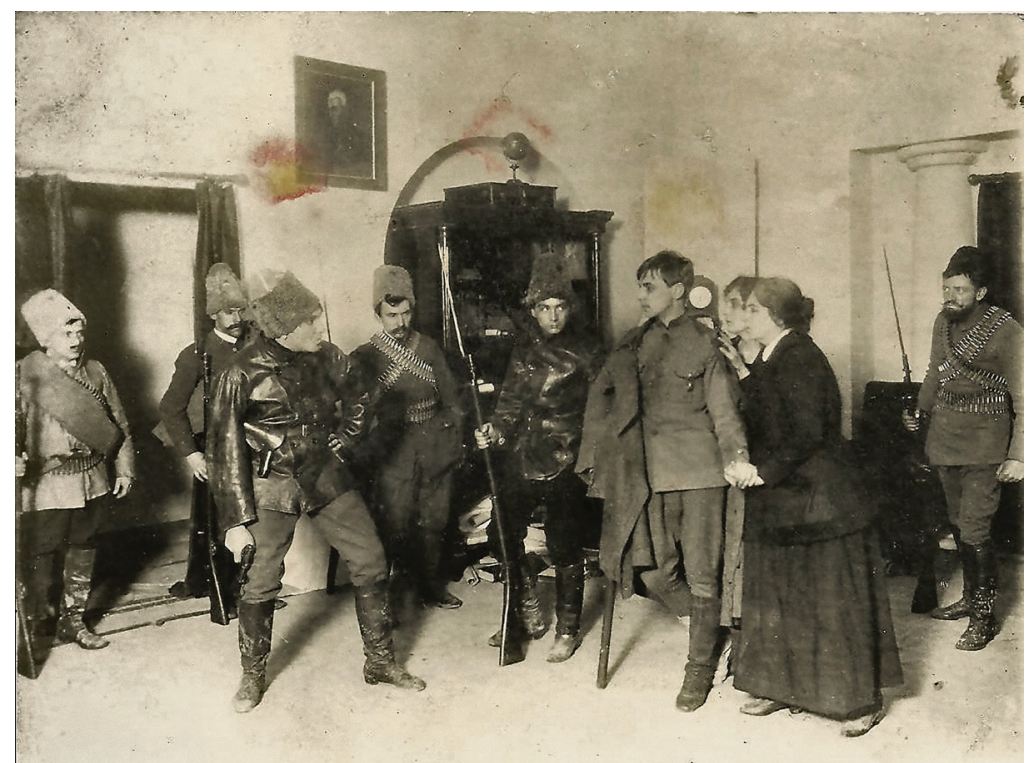

Scena z trzeciego aktu Ponad śnieg bielszym się stanę Żeromskiego, w reż. J. Osterwy, Teatr Reduta w Warszawie, Instytut Teatralny im. Z. Raszewskiego

nia i zahamowania teatralnego życia polskiego, akcja maskowana gołosłownymi wystąpieniami w teorii, której praktyka tak jaskrawo zaprzecza? ${ }^{18}$

W tym kontekście pojawienie się Reduty z jej - bardzo ograniczającym artystycznie - założeniem, że grać będzie wyłącznie utwory polskie, wydaje się nieprzypadkowe. Juliusz Osterwa, jak wiadomo, patrzył szerzej niż tylko w horyzoncie teatru $^{19}$. Postawa społecznikowska i obywatelska była w nim równie silna jak powołanie artystyczne. Gdy Polska odzyskiwała niepodległość, Osterwa był już dojrzałym człowiekiem i świadomym swojego posłannictwa artystą. Można się jednak zastanawiać, w jaki sposób uzyskał dla swego zespołu i nowego teatru tak prestiżową lokalizację jak Sale Redutowe. Prawdopodobnie potrzeba czysto „polskiej” sceny, sceny z ,ideą”, o którą upominali się autorzy prawicowi, była podzielana przez szersze grono osób.

Do zastanowienia skłania również decyzja Osterwy, by niespełna miesiąc przed inauguracją zmienić jej scenariusz. W próbach było $W$ małym domku Ta-

18 S. Pieńkowski, Teatr Mały, „Gazeta Warszawska” 1919 nr 326 (29 XI), https://crispa.uw.edu.pl/ object/files/146089/display/Default [dostęp: 22 VI 2020].

${ }_{19} \mathrm{Na}$ temat społecznikowskiej pasji Juliusza Osterwy zob. W. Świątkowska, Koncepcje teatru spotecznie zaangażowanego, „Pamiętnik Teatralny” 2018 z, 3, s. 146-168, https://doi.org/10.36744/pt.423 [dostęp: 22 VI 2020]. 
deusza Rittnera, dramat wymarzony wprost dla sceny, która miała być polskim odpowiednikiem Studia Moskiewskiego Teatru Artystycznego. Osterwa jednak, zapoznawszy się ze świeżo ukończoną sztuką Stefana Żeromskiego Ponad śnieg bielszym się stanę, postanowił właśnie tym dramatem otworzyć działalność Teatru Reduta. Co więcej, wbrew założeniom, że próby w Reducie będą długie i pozwolą aktorom skupić się należycie na tekście, dał premierę po zaledwie trzech tygodniach. Jaki wzgląd okazał się ważniejszy niż te czysto artystyczne? Zwłaszcza że w sensie teatralnym sztuka Żeromskiego jest mniej udana niż solidny dramat mieszczański Rittnera. Krytycy słusznie zwracali uwagę na jej niespójność gatunkową ${ }^{20}$. Jak zauważył przenikliwie Pieńkowski, są to ,właściwie dwa różne dramaty (akt I i III) przedzielone trzecim, mieszczańskim (akt II)"21. Osterwa, wytrawny już w tym okresie aktor, doskonale odróżniał sztuki dobrze napisane, od tych, które nie są materiałem na teatralny przebój.

Wybór tekstu i data premiery Ponad śnieg nie były przypadkowe. Inaugurując działalność Teatru Reduta 29 listopada 1919, a więc w rocznicę wybuchu powstania listopadowego, Osterwa myślał zapewne o dramacie Żeromskiego w kategoriach mobilizacji do obrony Polski. I rzeczywiście, kilka miesięcy później grał go dla żołnierzy-ochotników wyruszających na wojnę z bolszewikami. W prowadzonym zaś w tym czasie raptularzu naszkicował scenariusz niemego filmu na podstawie tej sztuki - filmu niewątpliwie mającego służyć propagandzie antykomunistycznej ${ }^{22}$.

\section{W SYTUACJI ZAGROŻENIA}

Niepodległość wykuwała się nieomal na każdym kilometrze polskiej granicy ustalonej w traktacie wersalskim. Na terenach przygranicznych toczyły się walki i spory: wojna z Niemcami wisiała na włosku, trwały utarczki zbrojne z Ukraińcami, wybuchały konflikty z Litwinami o Wilno i nie tylko, toczyły się walki o Śląsk Cieszyński, organizowano plebiscyt na Górnym Śląsku, otwarty był front galicyjski, od początku 1919 ślimaczyła się wojna polsko-bolszewicka.

Konflikt z Rosją sowiecką przybrał formę wojny, którą teraz nazywamy hybrydową. Polska poddana została infiltracji bolszewickiej, w wielu miastach namawiano robotników do strajków i buntu. To samo działo się na terenie Niemiec

20 Zob. M. Białota, Dramaty Żeromskiego w Reducie. Z zagadnień, inscenizacji i recepcji krytycznej, Wrocław 1989, s. 32-33.

${ }^{21}$ S. Pieńkowski, Wieczory teatralne. Teatr Reduta „Ponad śnieg” St. Żeromskiego, „Gazeta Warszawska" 1919 nr 331 (4 XII), https://crispa.uw.edu.pl/object/files/146084/display/Default [dostęp: 22 VI 2020].

22 J. Osterwa, Raptularz kijowski, oprac. I. Guszpit, Wrocław 2010, s. 351-357. 


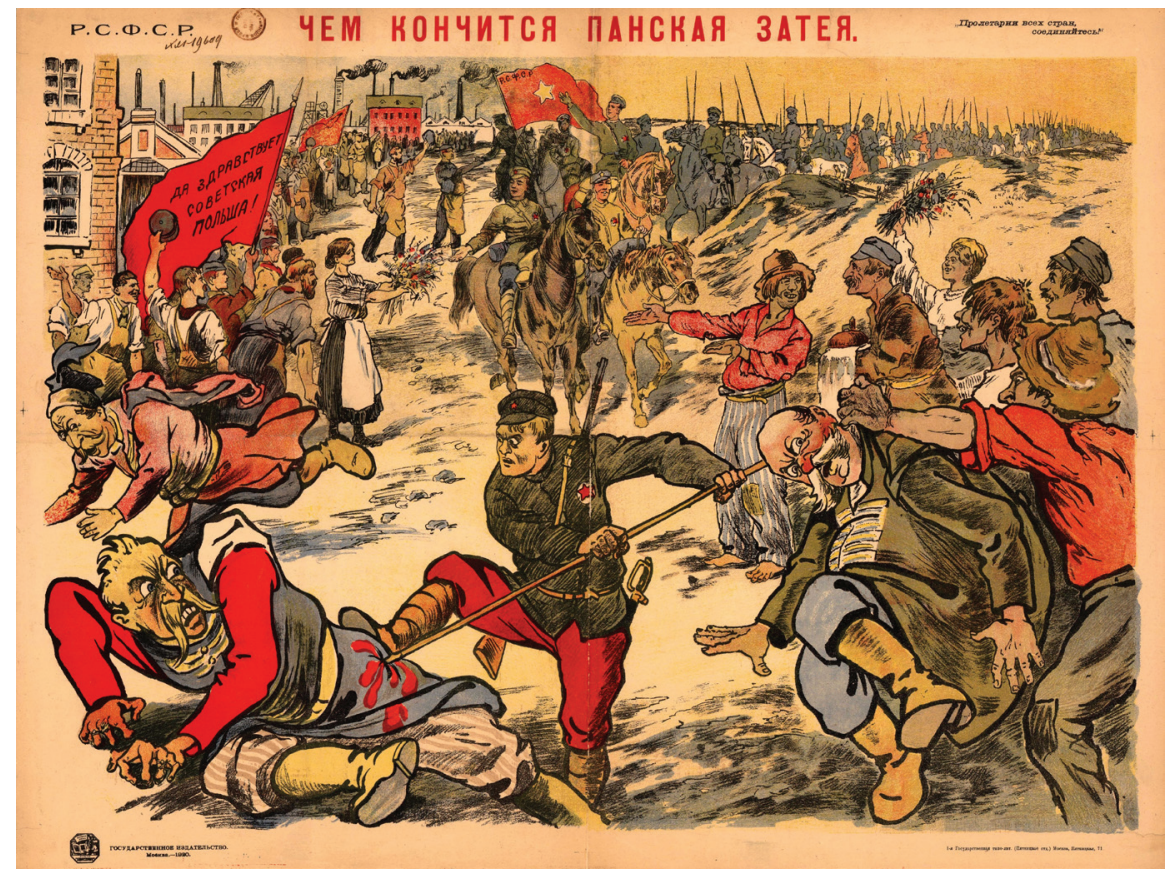

Bolszewicki plakat propagandowy „Czym kończą się pańskie pomysły”, Rosyjska Biblioteka Państwowa

na jeszcze większą skalę, co doprowadziło do tego, że rząd niemiecki wysłał wojsko na strajkujących. Gazety w kwietniu donosiły ${ }^{23}$, że dziennik premiera Francji Georges'a Clemenceau „L'Homme Libre” zamieścił artykuł pod tytułem Wszechbolszewizm, opisujący dokument uchwalony na tajnym zebraniu pod przewodnictwem Lenina i przy udziale Trockiego i Cziczerina. Dokument dotyczący spraw międzynarodowych, wewnętrznych, ekonomicznych i wojskowych zawierał między innymi instrukcje odnoszące się do wywiadu oraz szpiegostwa wojskowego i politycznego. Zalecał wspieranie ruchów szowinistycznych i konfliktów narodowych, propagował podsycanie zatargów międzynarodowych poprzez agitację, a także organizowanie zamachów na reprezentantów państw zagranicznych w poszczególnych krajach. Ponadto: kompromitowanie ludzi zajmujących w danym kraju wysokie stanowiska, dokonywanie zamachów na przedstawicieli władzy, podsycanie antyrządowej agitacji, kolportowanie literatury propagującej wewnętrzne niesnaski, urządzanie strajków generalnych i częściowych, zwłaszcza

${ }^{23}$ Wszechbolszewizm. Instrukcja bolszewicka, „Gazeta Warszawska” 1919 nr 92 (3 IV), https:// crispa.uw.edu.pl/object/files/146311/display/Default [dostęp: 22 VI 2020]. 
kolejowych, psucie maszyn fabrycznych, wysadzanie mostów i szyn, zakłócanie dowozu zboża i żywności do miast, wywoływanie kryzysów finansowych i fałszowanie banknotów, prowadzenie agitacji politycznej w wojsku, wywoływanie konfliktów między oficerami a żołnierzami, urządzanie zamachów na wyższych oficerów, wysadzanie w powietrze arsenałów, przejmowanie transportów surowców przeznaczonych dla fabryk wojskowych, penetrowanie fortów, organizowanie wywiadu na froncie i na tyłach, również w marynarce wojennej, wreszcie tworzenie specjalnych komitetów bolszewickich w poszczególnych krajach.

Opisane $\mathrm{w}$ instrukcji działania przynosiły rzeczywiste skutki. Przez zachodnie i południowe Niemcy przechodziła fala rewolucyjna organizowana przez Związek Spartakusa Róży Luksemburg i Karla Liebknechta. W wielu miejscowościach Bawarii, Badenii i Wirtembergii oraz w obszarach przemysłowych nadreńskich doszło do gwałtownych rozruchów. Wszędzie wojska rządowe strzelały do strajkujących, zamykano fabryki i kopalnie, w wielu miastach dochodziło do rabunków. Strajki organizowane przez niezawisłych socjalistów i komunistów miały wyraźnie polityczny charakter mimo postulatów gospodarczych. Strajkujący domagali się utworzenia rad robotniczych, zniesienia konstytuanty niemieckiej, usunięcia wojsk rządowych z kopaln, fabryk i większych ośrodków przemysłowych. Niemiecki rząd ogłosił w całym Zagłębiu Ruhry stan oblężenia. Spartakusowcy domagali się uznania władzy rad robotniczych, zaprzestania wojny z Armią Czerwoną i sojuszu Niemiec z Rosją bolszewicką.

Podobne wydarzenia miały miejsce w Polsce:

Agitatorzy komunistyczni organizują bojówki, terroryzują ludność, wyznaczają nagrody za mordowanie wojskowych, wywołują wciąż strajki i skierowują je na drogę gwałtów, agitują przeciw poborowi, dezorganizują armię polską i wchodzą w porozumienie z armiami państw wrogich ${ }^{24}$.

Wieści nadchodzące ze Lwowa i z Wilna wzmagały poczucie zagrożenia ze strony Rosji bolszewickiej również w Polsce centralnej. Wanda Siemaszkowa, która przyjechała wtedy ze Lwowa ${ }^{25}$ do Warszawy i zagrała w Ponad śnieg główną rolę kobiecą, właścicielki kresowego dworu polskiego ginącej z rąk bolszewickich żołnierzy, w maju 1919 apelowała na łamach gazet warszawskich o wsparcie lwowian:

Nie zdają sobie tutaj ludzie sprawy z moralnej wartości mieszkańców Lwowa. Niewiele serc w Warszawie bije takim tętnem dla sprawy narodowej, jakiem tam biją serca wszystkie. Tutejsi lu-

${ }^{24}$ I. Hł., Walka z bolszewizmem, „Gazeta Warszawska” 1919 nr 94 (5 IV), https://crispa.uw.edu.pl/ object/files/146309/display/Default [dostęp: 22 VI 2020].

${ }_{25}$ O teatrze lwowskim w tym okresie zob. M. Szydłowska, Teatr Miejski we Lwowie u progu niepodległości (1918-1919), „Pamiętnik Teatralny” 2018 z. 3, s. 77-105, https://doi.org/10.36744/pt.420 [dostęp: 22 VI 2020]. 
dzie nie słyszą ostatnich słów bohaterów z pola walki. Lwowskie dzieci konając, szepczą z uśmiechem do matek: Mamo - Polska! [...] Przyjechałam tutaj z gorącą chęcią, aby ulżyć tym, których męki przez szereg miesięcy dzieliłam. Przyjechałam tu, aby stąd różnym lwowskim stowarzyszeniom, ochronkom i żołnierzom dopomóc. My, aktorzy lwowscy ocieramy się ciągle bezpośrednio o ból i nieszczęście. Próby odbywamy wśród huku armat, rannych nam znoszą niekiedy podczas przedstawienia. Pomimo to aktorzy na stanowisku trwają i dają możność żołnierzom zapominać na chwilę o mozołach walki. Zarząd miasta łoży sumy, aby teatr wytrwał. Za to mu cześć! Wyobrazić sobie nie możecie, jaki tam nastrój panuje w oblężonym grodzie. Wojsko polskie w stosunku do ludności cywilnej ożywione jest duchem dawnych rycerzy kresowych. Nie tylko broni jej, ale także wspiera i otacza opieką. We Lwowie wszyscy pracują. Żony profesorów uniwersytetu noszą wodę tak samo, jak żony wyrobników. Czy może sobie warszawianka, chrupiąca co dzień białe bułeczki, mająca służbę, światło, tramwaj, wyobrazić panią X lub Z, miesiącami robiącą wszystkie grubsze roboty, a oprócz zajęć domowych kilka godzin dziennie poświęcającą pracy społeczno-humanitarnej? My, artystki w dodatku do tego wszystkiego musimy brać udział w przedstawieniach. Powtarzam, celem mojego przyjazdu jest niesienie pomocy stąd - tam. W dniach 6 i 8 maja urządzam w Teatrze Polskim dwa wieczory na rzecz cierpiących mieszkańców Lwowa. Weźmie w nich udział kilku moich kolegów, a także artyści warszawscy. Zwracam się do Panów, byście za pośrednictwem Gazety zawezwali publiczność26.

\section{Równie przejmujące wieści docierały z Wilna:}

Przyjeżdżamy do Wilna. Widok miasta straszny! Znać tu kilkumiesięczne panowanie dziczy barbarzyńskiego wschodu. Zda się, że przeszła tu śmierć i każdemu zajrzała w oczy. Głód, nędza na każdym kroku. Suną wycieńczone postacie - szkielety ludzkie. A jednak z ich oczu bije jakiś moc, pogarda śmierci i duma. Przetrwali to piekło bolszewizmu i zwyciężyli. A teraz z okrzykiem - vae victis - idą śmiało na dalszą rozprawę, świadomi, że Polska potrzebuje ich zbiorowego czynu. Dzieci, uczniowie, skauci, kobiety niekiedy bose, robotnicy, mieszczanie, inteligencja - wszyscy uzbrojeni z karabinem na posterunku. Wilno - to drugi Lwów. Cześć Ci bohaterski grodzie! ${ }^{27}$

Mając na względzie atmosferę 1919, trudno dziwić się, że Osterwa podjął błyskawiczną decyzję, by na inaugurację swej sceny dać sztukę Żeromskiego, której ostatni akt tak streszczał Pieńkowski:

Akt trzeci: syn jako oficer wojsk polskich okaleczony - bez ręki i bez nogi wraca pod strzechę rodzinną. Pokutująca matka wita go w przerażeniu i boleści. Do dworku wpadają bolszewicy na czele tłumu wiejskiego, który paniczowi zbrodni nie zapomniał. Scena rewizji, gwałtów, wymiana zdań między Polakiem szlachcicem a chamem bolszewikiem na temat ziemi, Polski, wol-

${ }^{26}$ Misja artystów lwowskich, „Gazeta Warszawska” 1919 nr 119 (2 V), https://crispa.uw.edu.pl/object/files/146284/display/Default [dostęp: 22 VI 2020].

27 O polityke polska na Wschodzie. Apel do Sejmu, „Gazeta Warszawska” 1919 nr 128 (12 V), https://crispa.uw.edu.pl/object/files/13991/display/Default [dostęp: 22 VI 2020]. 
ności kultury, strzał rewolwerowy, którym pani domu zabija przywódcę bolszewików, za sceną rozstrzeliwanie i krzyk rozjuszonego tłumu, a na scenie kaleka - oficer z podniesionym kosturem, tragiczny i straszny, gotów do walki z żołdactwem, które natrze nań bagnetami. Zasłona ${ }^{28}$.

Dokonany przez Osterwę wybór repertuarowy niesie wiele znaczeń. Po pierwsze, jest to prapremiera sztuki wybitnego polskiego autora, już w tym momencie uważanego za klasyka współczesności. Po drugie, w dramacie pojawia się temat zagrożenia egzystencji narodu i kultury państwa, której przedstawicielami były osoby zgromadzone w teatrze. Po trzecie, główni bohaterowie - Wiko, jego matka, jego żona, młynarz Joachim - to charakterystyczne typy polskie, coś więcej niż tylko postaci dramatu. Jak podkreślał Pieńkowski, Wiko, człowiek słaby, ulega matce i żonie - silnym polskim kobietom, przywykłym do rządzenia pod nieobecność mężczyzn oddanych walce o niepodległość. Jednak w chwili zagrożenia militarnego także uległy Wiko sprawdza się jako żołnierz i obrońca słabszych, chociaż jest już kaleką. Osobą pełną godności, samodzielną w myśleniu i działaniu jest za to Joachim, młynarz, reprezentujący mądrość ludzi pracy na wsi. Takie ustawienie charakterologiczne najważniejszych postaci sztuki kojarzy się z Myślami nowoczesnego Polaka Romana Dmowskiego ${ }^{29}$, który w swym podstawowym dziele bezwzględnie chłoszcze polską szlachtę i zwalcza paradygmat romantyczny. Do związków Żeromskiego z Dmowskim wrócimy. Tymczasem należy przypomnieć rozważania, dyskusje i polemiki na temat specyfiki polskiej mentalności, nazywanej wtedy „duszą polską”, których częścią jest ten dramat. W okresie odzyskiwania niepodległości dyskusje te toczyły się we wszystkich gazetach polskich, szczególnie intensywnie jednak $\mathrm{w}$ prasie prawicowej.

\section{ZAGADKA POLSKIEJ DUSZY}

W rozszyfrowaniu zagadki polskiej duszy upatrywano sposobu na zaradzenie wynikającym z jej specyfiki klęskom, których efektem był, kończący się właśnie, okres braku państwowości. Obok publikacji w gazetach organizowano publiczne spotkania poświęcone temu problemowi. Również Mieczysław Limanowski wygłosił w kwietniu 1919 w Muzeum Przemysłu i Rolnictwa wykład zatytułowany Walka o dusze polska. Sala „dobrze się zapełniła”, mimo że Limanowski „nie

${ }^{28}$ S. Pieńkowski, Wieczory teatralne. Teatr Reduta „,Ponad śnieg”..., op. cit. (zob. przyp. 21).

${ }^{29}$ Podstawę dla pierwszego książkowego i podpisanego nazwiskiem autora wydania Myśli nowoczesnego Polaka z 1903 stanowiła seria artykułów Dmowskiego ukazująca się w 1902 na łamach „Przeglądu Wszechpolskiego”, sygnowana pseudonimem R. Skrzycki. Wydanie to miało nakład około 1000 egzemplarzy, kolejne ukazało się we Lwowie w 1904, a do końca II wojny światowej książkę wznawiano jeszcze pięciokrotnie. 
mógł jeszcze stać się w Warszawie modnym, zdaje się więc, że temat zwabił słuchaczy”30. Oto, jak relacjonował ten odczyt dziennikarz „Gazety Warszawskiej”:

Stajemy do współzawodnictwa z narodami wielkimi, tworzymy państwo, na które jeden świat liczy, a które drugie mają respektować, jak wody szanują tamę. Nieświadomi sił, zalęknieni dziejącą się burzą, brać mamy w siebie dusze, siedzącą na ramieniu - i tworzyć. Warszawa była punktem względnie spokojnym w tej wojnie, jak głąb oceanu. Zbywa jej na wyobraźni tego ruchu i wysiłku, który wytwarza dzieje. Czyjegoż to ducha tworzy? - pytają w teatrach i cukierniach. Ktoś z misji cudzoziemskiej powiedział:

- W Poznaniu widziałem naród polski, w Warszawie widzę ludność polską.

Otóż pytanie, z którym dążyliśmy na odczyt, dotyczyło tej duszy, która z ludności robi naród, z plazmy psychicznej tłumu - organizację osobowości narodowej.

P. Limanowski jest z tych wtajemniczonych, którzy tę duszę widzą. [...] Dusza polska - według p. L - ma dwa bieguny, jak każda dusza; jeden pozytywny, idealistyczny, skierowany ku osiąganiu wartości wszechludzkich, wiekuistych; drugi zaś odjemny, ziemski, namiętny w złem. Prelegent nazywa ten drugi pierwiastek Konradowym, pierwszy - mesjanistycznym. Umysł polski uświadomił sobie tę dwoistość dopiero po utracie wolności ${ }^{31}$.

W ujęciu „Gazety Warszawskiej” wywód prelegenta prowadził do wniosków, że „duch ziemi polskiej ma w naturze konstrukcyjność, dar budowania od wewnątrz [...] dar hierarchicznego budowania społeczeństwa. [...] Polska szła w słońce dopóki nie zburzyła tej hierarchii zarażona duchem Azji magnateria na Rusi”, pod której wpływem szlachta „uczyniła z ludu niewolnictwo” i podporządkowała sobie króla ${ }^{32}$.

Inny przykład tego typu rozważań to artykuł związanego z Narodową Demokracją historyka literatury Stanisława Cywińskiego O naczelnej wadzie polskiej ${ }^{33}$, w którym autor, rozmyślając o wadach Polaków, uznał, że choć trafne jest Norwidowe ujęcie słabości polskiej jako „braku formy”, to:

jeszcze lepiej i dobitniej ujmuje tę rzecz Berwiński w sławnym Don Juanie Poznańskim, gdy mówi o powstańcach z r. 1831:

,.... dnia trzeciego

Skończyli wedle zwyczaju

Szlachecko-polsko-narodowego

Bo nie skończyli dla kraju"

lub w tych lapidarnych słowach:

${ }^{30}$ Z Sali odczytowej: Mieczystaw Limanowski: Walka o duszę polska, „Gazeta Warszawska” 1919 nr 93 (4 IV), https://crispa.uw.edu.pl/object/files/146310/display/Default [dostęp: 22 VI 2020].

${ }^{31}$ Ibidem.

${ }^{32}$ Ibidem.

33 S. Cywiński, O naczelnej wadzie polskiej, „Gazeta Warszawska” 1919 nr 123 (7 V), https://crispa.uw.edu.pl/object/files/6454/display/Default [dostęp: 22 VI 2020]. 


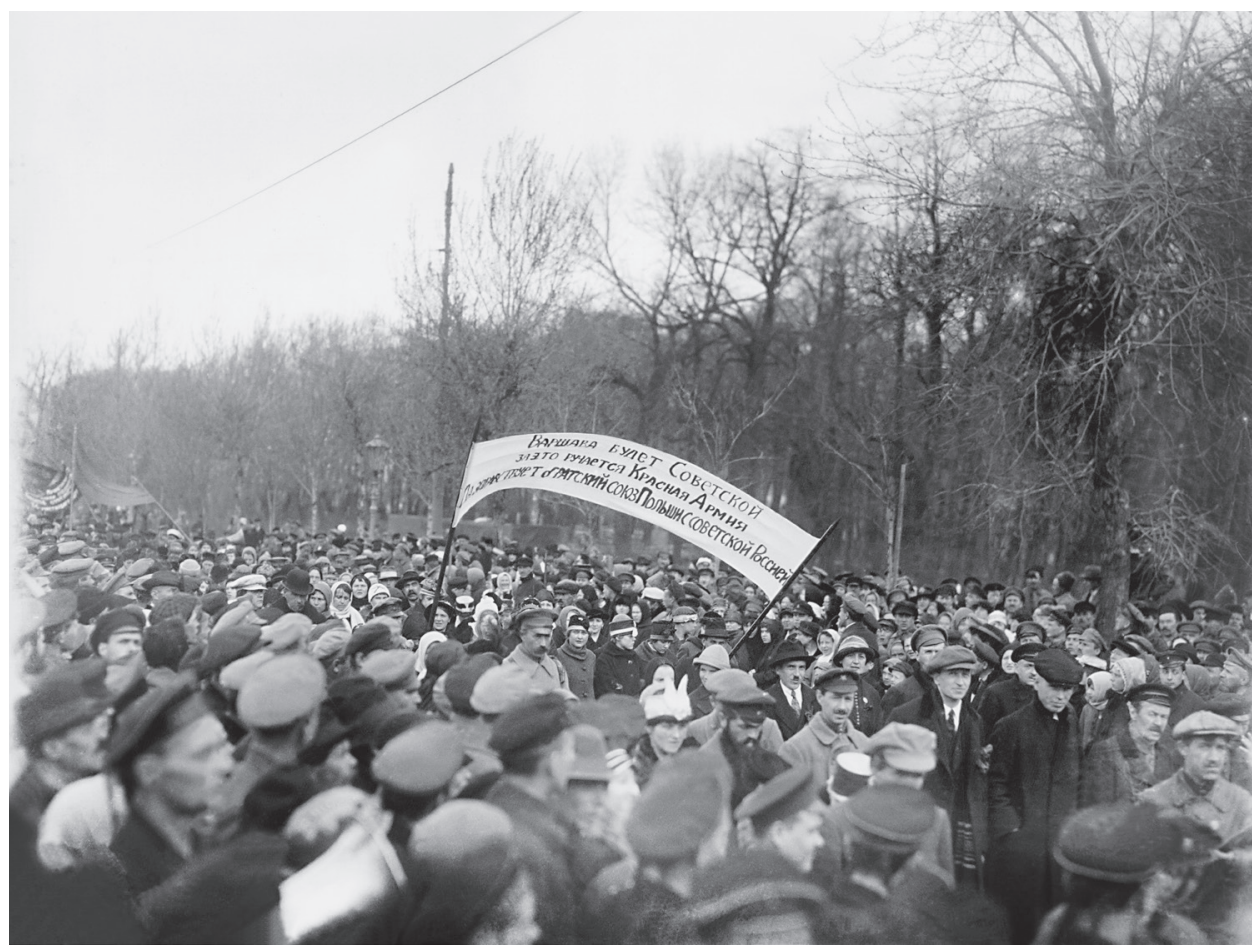

Pochód pierwszomajowy w Piotrogrodzie, 1920. Fot. @

„....skończyłem czysto po polsku,

bo nie skończyłem".

Cywiński konkluduje: „Brak wykończenia, brak cierpliwości, niezdolność doprowadzenia rzeczy do końca, brak formy, tak - brak formy!”. Forma to słowo-klucz, które opisuje, czego oczekiwano od polskiego teatru narodowego.

\section{O FORMĘ TEATRU POLSKIEGO}

Dla strony prawicowej ważny był bowiem nie tylko repertuar, lecz także forma nowoczesnego teatru polskiego. Prawicowa krytyka nie ukrywała, że czeka na nowego polskiego teatralnego mesjasza, ponieważ starsi artyści nie są już w stanie stworzyć lepszego modelu teatru. Po występach czołowej tragiczki polskiej sceny, Stanisławy Wysockiej, w reżyserowanej przez nią Lilli Wenedzie, Pieńkowski, znający artystkę z Kijowa jako założycielkę studyjnej sceny, pisał brutalnie i jasno: 
Sposób jej reżyserii według kanonu - romantyczny. Pusta deklamacja, czcza gestykulacja, teatralna pozeria, trochę prostaczego komizmu - oto prosta całość, która jeszcze bardziej osłabiła utwór z natury już słaby. Można go było w wielu miejscach pogłębić grą i reżyserią bez maniery, ale reżyser poszedł $\mathrm{w}$ przeciwnym kierunku aż do melodramatycznej rutyny. [...] Głosy, jak zwykle u nas, oparte na wykrzykiwaniu ról bez najmniejszego dążenia do barwy i intonacji, co zresztą już owa zasada deklamowania z góry wyklucza. [...] Rutyna wciąż panuje w teatrze i nie dopuszcza doń sztuki. Czekam, ale już nie mam nadziei na te teatry warszawskie, które istnieją obecnie. Dużo w nich autoreklamy, wiele zapowiedzi, szeptów tajemniczych za kulisami, kadzidlanego dymu kapliczek, ale prostoty i głębi, skąd bije źródło sztuki wielkiej - nie ma w nich i nie będzie. Musi tu przyjść ktoś nowy, ktoś bezwzględny i czysty ${ }^{34}$.

Kimś „nowym, bezwzględnym i czystym” miał być Juliusz Osterwa. „Gazeta Warszawska" uważnie i życzliwie śledzi postępy w budowaniu przestrzeni dla nowego i nowoczesnego teatru:

W nadchodzącą sobotę, dnia 29 b.[ieżącego] m.[iesiąca] nastąpi otwarcie miejskiego teatru kameralnego Reduta. Nowy teatr mieści się w Salach Redutowych. Piękna sala kameralna, zbudowana według projektu architekta Jawornickiego, urządzona jest tak, że może być całkowicie rozebrana w przeciągu sześciu godzin. Konstrukcja zasadnicza Sal Redutowych, należących do naszych cennych zabytków przeszłości, została nietknięta. Widownia pomieszczona pośrodku Sal Redutowych, zbudowana jest amfiteatralnie. Z balkonów użyty został tylko jeden, dla dwudziestu kilku osób. Sale przygotowano ściśle do zadań teatru kameralnego, t.j. urządzono ją tak, iż dla sztuk wymagających większego skupienia i bliższego kontaktu z widzem, estrada może być usunięta zupełnie, aby widowisko odbywać się mogło na tym samym poziomie, co pierwsze rzędy krzeseł ${ }^{35}$.

Nowinki teatralne, jak scena na podłodze, nie zniechęcają konserwatywnego dziennika. Gazeta podkreśla przy innej okazji z podobną atencją: „budka suflera zniesiona zupełnie. Repertuar przewiduje sztuki wyłącznie oryginalne" Po inauguracji Reduta jest chwalona za nowoczesne podejście do zespołowości i przestrzeni. Stanisław Pieńkowski pisze, że zazwyczaj w teatrze scena jest mała, a widownia ogromna, bo względy merkantylne o tym decydują, a w Reducie jest odwrotnie: ,budzi się wreszcie nowy ruch artystyczny, który względy kasowe usuwa, a na pierwszy plan stawia sztukę"37. Tym razem jednak autor recenzji zwraca uwagę, że scena na poziomie podłogi to równie niefortunne

34 S. Pieńkowski, Wieczory teatralne. Teatr Rozmaitości „Lilla Weneda”, "Gazeta Warszawska” 1920 nr 234 (27 VIII), https://polona.pl/item/gazeta-warszawska-r-140-nr-234-27-sierpnia-1920,NzU3NzMxMg/3/\#info:metadata [dostęp: 22 VI 2020].

35 „Gazeta Warszawska” 1919 nr 320 (23 XI), https://crispa.uw.edu.pl/object/files/146095/display/ Default [dostęp: 22 VI 2020].

36 Ibidem.

37 S. Pieńkowski, Wieczory teatralne. Teatr Reduta „Ponad śnieg”..., op. cit. (zob. przyp. 21). 
rozwiązanie jak bardzo wysoka scena w Teatrze Letnim, i zaznacza, że najlepiej usytuowaną scenę ma Teatr Polski. Pociesza go informacja, że teatr podobno posiada „ruchomą estradę, którą w razie potrzeby podnosi” oraz że ma „kierownika plastyki scenicznej, pana Zbigniewa Pronaszkę”, który „powinien sprawę tę rozstrzygnąć" ${ }^{38}$. Chwali dalej brak suflera i kolejną korzyść wynikającą z małej widowni - sztuka idzie długo i zespół ma czas, by sumiennie przygotować kolejną premierę. Zmianę podejścia do sztuki teatru zapowiada jednak przede wszystkim nowy typ zespołu:

Oprócz powyższych ulepszeń natury czysto technicznej Reduta pragnie położyć nacisk na zespół sceniczny i zrywa z tradycją gier poszczególnych indywidualności niezwiązanych z całością. Obrońcy tradycji utrzymują, że tym sposobem gwałci się i zaciera wybitne talenty aktorskie, które też jakoby, z takich scen uciekają. Lecz to jest nieprawda. Chodzi właśnie o zespół różnych indywidualności, dla których władza reżysera nie jest dyktaturą, lecz tylko batutą najprostszych i koniecznych w każdym dziele sztuki wytycznych harmonii ogólnej. Sztuka sceniczna jest sztuką zbiorową. [...] tę harmonię całości otrzymała widownia istotnie na otwarciu teatru Reduta w dramacie Stefana Żeromskiego Ponad śnieg ${ }^{39}$.

\section{DO BRONI!}

Kilka miesięcy później, w drugiej połowie 1920 te wszystkie względy przestały się liczyć. Podczas inwazji bolszewickiej rolą artysty narodowego nie było już uprawianie sztuki narodowej w treści, a nowoczesnej w formie, ale wcielanie w życie postawy obywatelskiej. Zaczęło się od apelu Pieńkowskiego na łamach „Gazety Warszawskiej”. W tekście o sugestywnym tytule Groza opisywał, jak w Teatrze Polskim wszyscy się bawią i nikt, nawet obecna na widowni dyrekcja, nie reaguje na rozrzucane z balkonu ulotki Rady Obrony Państwa. Pieńkowski zastanawia się, kiedy Warszawa zrozumie powagę sytuacji:

Słyszycie? Idzie, idzie na Polskę groza pożarów i mordu. Jeśli nie chcecie, by kamień na kamieniu tu nie został, wśród trupów pomordowanych żon waszych, matek i dzieci. Rzucajcie wszystko, co zbytkiem jest i sprawą dla bytu państwa niekonieczną i idźcie pod rozkazy wodza. Jeszcze czas, jeszcze wysiłek wasz i poryw zatrzymać może u granic kraju huragan dzikich hord, a wewnątrz - zdeptać wężowisko gadów zdradzieckich. Lecz jutro już może być za późno. Więc spieszcie z pomocą braciom i synom walczącym na froncie ${ }^{40}$.

\footnotetext{
${ }^{38}$ Ibidem.
}

39 Ibidem.

40 S. Pieńkowski, Groza, „Gazeta Warszawska” 1920 nr 183 (7 VII), https://polona.pl/item/gazetawarszawska-r-140-nr-183-7-lipca-1920,MTEzNjg1OTcx/1/\#info:metadata [dostęp: 22 VI 2020]. 
Uruchomiona hasłem „Do broni!” akcja nawoływania do rekrutacji armii ochotniczej objęła z czasem wszystkie środowiska w Polsce. Ludzi teatru nie poddawano jednak tego rodzaju naciskom. Powszechnie czytany „Tygodnik Ilustrowany" piętnował przede wszystkim odbiorców sztuki teatru i filmu, relacjonując wyniki akcji:

Owocną akcję w tym kierunku przedsięwzięto we wszystkich miejscach publicznych. Ludzie oddani rozrywkom wysłuchać muszą gorzkich i twardych słów prawdy. Rozlegają się dziś one we wszystkich kinach i teatrach warszawskich, w tym, mniej więcej brzmieniu: „Nie wasze tu miejsce, co się mienicie być mężami, a za matczyną, żoniną spódnicą się chowacie, aby tylko głosu Ojczyzny, o pomoc wołającej, nie słyszeć... Na ustach macie słowa obowiązku dla innych, nie dla siebie, potraficie tylko siać ziarna niewiary, z których wyrasta strach i bezrząd. Na wołanie Ojczyzny odpowiadacie: Niech idą inni, ja mam obowiązki. Wobec kogo?... Wiesz ty, co czeka twoją matkę, jeśli tu przyjdą hordy czerwone? Czy myślisz, że oni matki ci nie splugawią, nie zamordują... Czy może o żonę ci idzie? A wiesz ty, mężu zatroskany, co robią z kobietami czerwonogwardiejscy?... Siedź tu i czekaj, aż tę kobietę, która z tobą pracowała przez całe życie, która ci zaufała, że będziesz jej obrońcą, zhańbią, a później zabiją... [...]

Wszyscy mężczyźni na front, wszyscy... kogo brak w szeregach, kto nie na służbie ojczyzny, kto w takiej chwili chowa się, ten nie wart, by dla niego świeciło słońce, nie wart, by choć jedna kobieta w Polsce miała dla niego uśmiech i dobre słowo. Tak, za karabin i na front! My, kobiety, wiemy co nam uczynić wypada. Każda z nas odda wszystko, co może, dla Polski. Przetrząśniemy nasze domy i co tylko przydać się może żołnierzowi oddamy obrońcom. Pójdziemy do szpitali. Zaciągniemy się do służby miłosierdzia. Nie kupimy sobie, ani nikomu ze swoich nic, prócz tego, co do życia niezbędne. Każdy grosz dla Ojczyzny... Nie pozwolimy, by wyrzucano za darmo grosz, o który Ojczyzna woła. Tchórzom, tym, co się kryją przed wrogiem, hańba i pogarda. Polska, Ojczyzna nasza, niech żyje!’’41

Środowisko teatralne zastanawiało się jednak, jak postąpić w sytuacji, gdy większość narodu w ten czy inny sposób mobilizuje się do walki czynnej. „Tygodnik Ilustrowany" tak podsumowywał podjętą podczas wiecu aktorskiego dyskusję wokół pytania, czy teatry powinny grać:

Samo zastanowienie się nad tą sprawą oraz jasne i odważne sformułowanie pytania przez ogół aktorski bez innego przymusu, niż moralny (bo publiczność uczęszcza do teatru po dawnemu i nie wzbudziła alarmów jej abstynencja) - świadczy nadzwyczaj korzystnie o naszych artystach: pragną oni jak najużyteczniej służyć Ojczyźnie. Wyrazili gotowość porzucenia pola swej zawodowej pracy i chwały, aby gdzie indziej i czym innym, mianowicie bezimiennym znojem i nie ,artystyczną" krwią służyć sprawie ojczystej. Po sumiennej dyskusji zgodzono się, iż na

${ }^{41}$ S. M. [Stanisław Miłaszewski], Z dni, w których losy ojczyzny się waża, , Tygodnik Ilustrowany” $1920 \mathrm{nr} 31$ (31 VII), s. 620, https://bcul.lib.uni.lodz.pl/dlibra/publication/242/edition/145/content?re$\mathrm{f}=$ desc [dostęp: 22 VI 2020]. 
razie nie ma potrzeby, by wszyscy aktorzy bez względu na wiek stawali pod bronią lub żeby wszystkie aktorki oddały się wyłącznie posługom szpitalnym. Te obowiązki spełnią młodsi i silniejsi. Inni będą służyli krajowi w zakresie swojego zawodu, formując kadry propagandowe, objeżdżając front bojowy i kresowe obszary. Postanowienie słuszne i rozumne. Ponieważ jednak posiadamy w stolicy bardzo znaczny zasób sił artystycznych [...] przeto nie ma obawy, aby stworzenie teatrów propagandowych spowodować musiało zamknięcie ważniejszych scen dramatycznych w Warszawie. Należy raczej postarać się o to, żeby sceny miejscowe, osiągnąwszy najwyższy poziom artystyczny, stały się również ogniskami szlachetnej propagandy ducha narodowego i oddziaływały dodatnio na ludność cywilną wszystkich stanów. [...] Godzi się przewidywać, iż projektowane teatry objazdowe zabiorą wielu pierwszorzędnych artystów ze wszystkich teatrów miejscowych. Aby zaś te ostatnie wskutek braku sił aktorskich nie obniżyły jeszcze i tak już niewysokiego repertuaru (co nadałoby im wreszcie charakter ognisk propagandy wręcz szkodliwej i szerzącej bezmyślność w sercu kraju!), muszą, moim zdaniem, zawrzeć pakt i wspomagać się nawzajem. Podobne współdziałanie będzie możliwe tylko wówczas, jeśli dyrekcje warszawskich teatrów dramatycznych ułożą społem repertuar dla stołecznych scen i porozumieją się co do wymiany aktorów. Powaga chwili obecnej wymaga, ażeby o ile możności życie normalne poza frontem nie słabło. Kabarety i teatrzyki o wiele przydatniejsze byłyby dla żołnierza, podobno żądnego nieraz pustej rozrywki po tragicznych wstrząśnieniach walki, niż dla mieszkańców stolicy, których kulturę moralną i obywatelską kształtować winien teatr poważny. Powtarzałem już wielokrotnie i powtarzam jeszcze, iż pierwszą czynnością świadomego i odpowiedzialnego kierownika teatru winno być ułożenie planu repertuarowego i związane z tym, jako pierwsza realizacja, dobieranie zespołu aktorskiego. Teatr szukający repertuaru dla zorganizowanego bezcelowo zespołu albo chorzeje dyskretnie, albo - w gorszym wypadku - zaraża inne sceny jawną niemocą. [...] niechże czynniki miarodajne i kierownicy teatrów [...] ocalą byt i ulepszą poziom scen stołecznych, nie zaniedbując równocześnie obowiązku wobec armii i kresów. Niechaj się przyczynią do przetworzenia publiczności w naród. Inaczej przyjdzie skierować pod zmienionym adresem pyszną lokucję Grzymały-Siedleckiego ,umieli się panoszyć, nie umieli panować"42.

Miesiąc po ukazaniu się tego tekstu zespół Reduty już nie gra w Warszawie. Podobnie jak Osterwa znika ze stolicy również Pieńkowski, który jeszcze w czerwcu zaangażował się w organizowanie pisma poświęconego ,sprawie obrony narodowej” „Ochotnik” (pisał tam m.in. Makuszyński). Obaj wracają po miesiącu, podczas którego Pieńkowskiego, głównego recenzenta endeckiego dziennika, i Osterwę, ,nowego, czystego" twórcę narodowego modelu sceny, łączyło prze-

42 S. Miłaszewski, Życie i teatr, ,Tygodnik Ilustrowany” $1920 \mathrm{nr} 32$ (7 VIII), s. 624, https://bcul. lib.uni.lodz.pl/dlibra/publication/242/edition/145/content?ref=desc [dostęp: 22 VI 2020]. A. Grzymała-Siedlecki wydał w Warszawie w 1921 zbiór reportaży z frontu wojny polsko-bolszewickiej Cud Wisty Wspomnienia korespondenta wojennego. Nie wspomniał tam jednak w ogóle o przedstawieniach teatralnych urządzanych w tym okresie dla żołnierzy czy ludności przyfrontowej, mimo że grane były między innymi jego sztuki. 


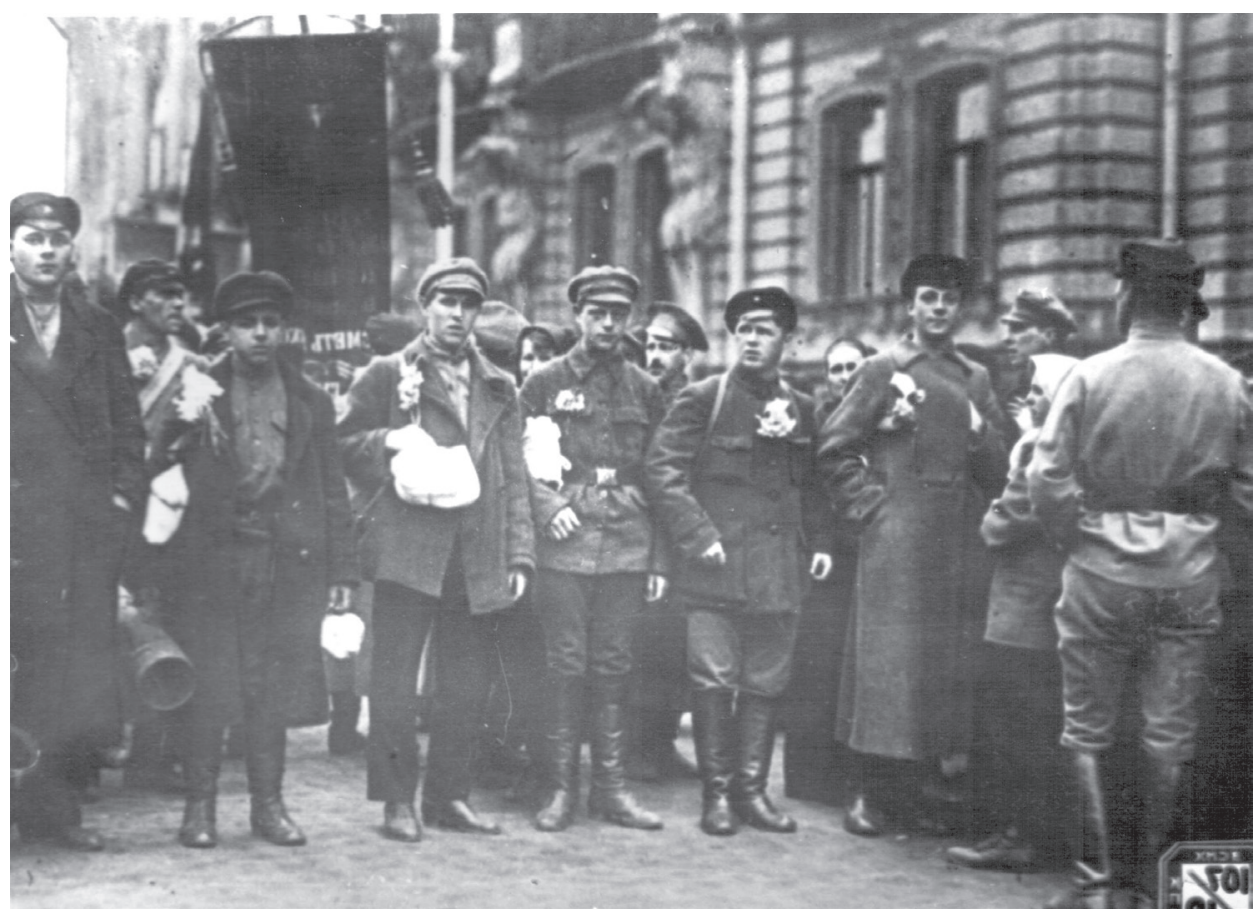

Wymarsz komunistów na front polski, Piotrogród 1920. Fot. @

konanie, że w tym szczególnym momencie dziejowym rola teatru w kształtowaniu nowoczesnego narodu polegać powinna na dzieleniu trudu żołnierza polskiego.

\section{KRĄG ELITY PRAWICOWEJ}

Świadome i zdecydowane działania Osterwy na rzecz stworzenia polskiej sceny narodowej w okresie odzyskiwania niepodległości i wojny polsko-bolszewickiej były zapewne pochodną nie tylko jego osobistych predyspozycji, lecz także wpływu prawicowej elity, w której kręgu pozostawał. Wzajemne kontakty sprawiały, że te środowiska widziały w nim i jego zespole nadzieję na powstanie teatru zgodnego z ich wyobrażeniem o narodowej scenie. Stefan Żeromski i Wincenty Lutosławski, bliscy Osterwie w tym okresie, mieli w biografiach krótsze lub dłuższe związki intelektualne z Romanem Dmowskim.

Żeromski we wczesnej młodości, w 1893, robił korektę wydanej w Paryżu broszury Dmowskiego Gimnazja rosyjskie w Polsce. Cywiński twierdzi, że kore- 


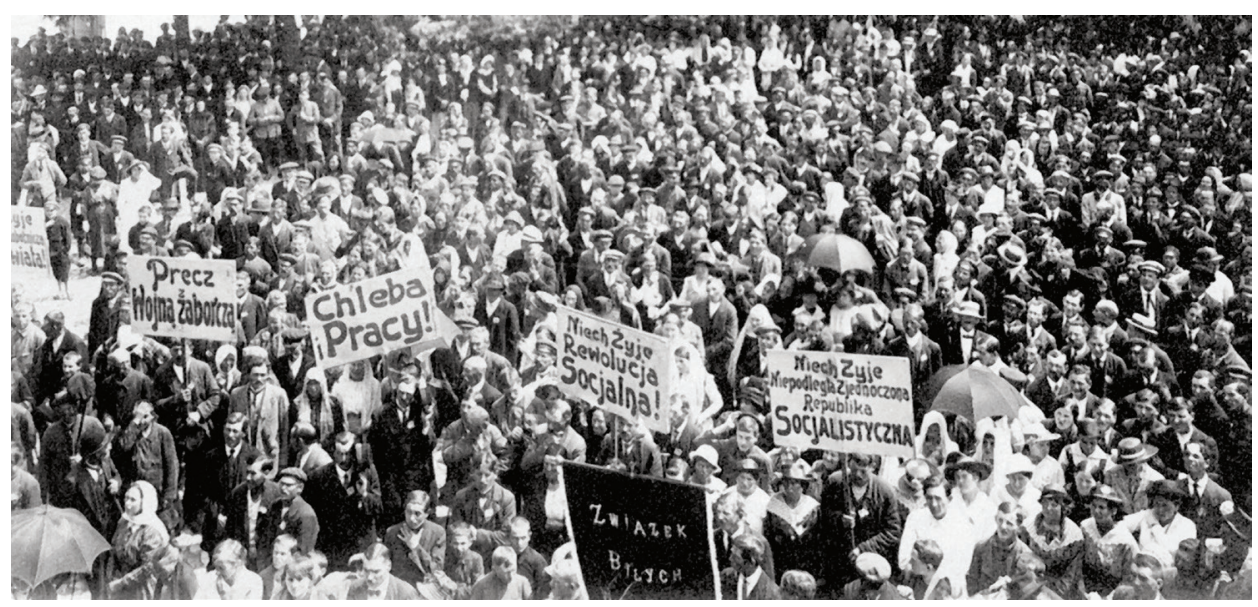

Demonstracja pierwszomajowa w Warszawie, 1920, Centralne Archiwum Wojskowe w Warszawie

spondował wówczas z Dmowskim i że właśnie pod jego wpływem pisał pierwszą wersję Syzyfowych prac ${ }^{43}$. Żeromski - krytycznie nastawiony do polskiej literatury $^{44}$ i kojarzony z poglądami socjalistycznymi - niewątpliwie przez pewien czas pozostawał pod wpływem osobowości Dmowskiego i głoszonych przez niego idei. Świadectwem jego przekonania, że walka o niepodległość ma bezwzględne pierwszeństwo przed walką klasową, jest napisana w październiku 1918, wydana zaś w Krakowie na początku 1919 broszura Początek świata pracy. Żeromski przestrzega w niej Polaków przed bolszewizmem i przed tymi, którzy prowadzą sprawę Polski „krzywym łukiem rewolucji”45. Julian Marchlewski odpowiedział na tę broszurę listem otwartym, w którym przypominał Żeromskiemu „chwile gawędy o falansterach Bodzanty, toczonej ongi z Wami, obywatelu, w Warszawie, w okresie walk rewolucyjnych lat temu kilkanaście"46. Marchlewski był w sposób szczególny zaangażowany w bezskuteczne pertraktacje z polskim rządem w okresie wojny polsko-bolszewickiej ${ }^{47}$. Rozżalony postawą Żeromskiego długo pracował

43 Zob.: S. Żeromski, Dzienniki, oprac. J. Kądziela, t. 7, Warszawa 1970, s. 468; S. Pigoń, U początków ,,Syzyfowych prac”, [w:] idem, Miłe życia drobiazgi, Warszawa 1964, s. 320-435; B. Cywiński, Rodowody niepokornych, Paris 1985, s. 10. Notabene Pigoń był wychowankiem Lutosławskiego i zarazem endekiem.

44 Zob. np. S. Żeromski, Literatura a życie polskie, [w:] idem, Sen o szpadzie i sen o chlebie, Zakopane 1916.

45 J. Marchlewski, Listy do Stefana Żeromskiego i Władysława Orkana, oprac. A. Słapa, Kraków 1953, s. 128.

46 Ibidem, s. 127-128.

47 Zob. N. Davies, Orzet biaty, czerwona gwiazda: wojna polsko-bolszewicka 1919-1920, przeł. A. Pawelec, Kraków 2006. 
nad swym listem otwartym, by wyjaśnić pisarzowi idee rewolucji ${ }^{48}$. Żeromski potraktował go jednak jako zdrajcę polskiej sprawy w reportażu z frontu wojny polsko-bolszewickiej ${ }^{49}$.

Różnorakie związki z Dmowskim miał też Wincenty Lutosławski, filozof i myśliciel, który usiłował wychować całe pokolenie Polaków poprzez organizację Eleusis, jeden z mentorów intelektualnych Osterwy ${ }^{50}$. Lutosławski i Osterwa jeszcze w 1943 wymieniali listy zawierające deklaracje etyczne i rozważania historiozoficzne dotyczące misji Polski ${ }^{51}$. Pierwsze spotkanie Lutosławskiego z Dmowskim wspominała na łamach londyńskiej „Myśli Polskiej” córka filozofa, Izabella z Lutosławskich Wolikowska:

Poznanie się moich rodziców z Panem Romanem nastąpiło w Krakowie na początku wieku. Nie znam drugiego wypadku tego rodzaju - choć na pewno zdarzają się - by człowiek obcy i zupełnie odmiennego środowiska, stał się od razu wprost członkiem rodziny i to, na całe życie ${ }^{52}$.

Z opisu Lutosławskiej wynika, że jej rodzice poznali się z Dmowskim, gdy ten pisał Myśli nowoczesnego Polaka. W krakowskim salonie Lutosławskich w 1902 spotkał Dmowskiego również Stanisław Wyspiański, a Myśli nowoczesnego Polaka wpłynęły na kształt jego Wyzwolenia ${ }^{53}$, tak bliskiego Osterwie identyfikującemu się z Konradem. W latach 1919-1920 Lutosławski chętnie publikował na

48 J. Marchlewski, op. cit., s. 127-148.

49 „Na odgłos strzałów, rozlegających się za Bugiem dr. Julian Marchlewski, jego kolega Feliks Dzierżyński pomazany od stóp do głów krwią ludzką, i szanowny weteran socjalizmu Feliks Kohn - dali drapaka z Wyszkowa. Pozostał po nich tylko wielki swąd spalonej benzyny, trocha cukru, oraz wspomnienie dyskursów, prowadzonych przy stole i pod jabłoniami cienistego sadu. Przed wyjazdem dr. Julian Marchlewski powtarzał raz wraz melancholijnie: «Miałeś, chłopie, złoty róg/Miałeś, chłopie, czapkę z piór.../Został ci się ino sznur»... Jak w wielu innych rzeczach, tak i tutaj, niedoszły władca mylił się zasadniczo. Złotego rogu Polski, wcale w ręku nie trzymał. Czapka krakowska również mu nie przystoi. Jeżeli jaki strój, to już chyba okrągła, aksamitna czapeczka moskiewska, obstawiona wokoło pawimi piórami prędzej mu będzie pasowała. Tę już do końca życia nosić mu wypadnie. Nawet do biednego sznura od polskiego złotego rogu nie ma prawa ten najeźdźca. Kto na ziemię ojczystą, chociażby grzeszną i złą, wroga odwiecznego naprowadził, zdeptał ją, stratował, splądrował, spalił, złupił rękoma cudzoziemskiego żołdactwa, ten się wyzuł z ojczyzny. Nie może ona być dla niego już nigdy domem, ni miejscem spoczynku. Na ziemi polskiej nie ma dla tych ludzi już ani tyle miejsca, ile zajmą stopy człowieka, ani tyle, ile zajmie mogiła", S. Żeromski, Na probostwie w Wyszkowie, [w] idem, Inter arma, Warszawa 1920, s. 70 -71, https://polona.pl/item/inter-arma,Njg2Mjk5OQ/38/\#info:metadata [dostęp: 22 VI 2020].

${ }_{50}$ Zob. J. Szczublewski, Żywot..., op. cit., s. 68. O relacji Osterwy z Lutosławskim pisze w tym zeszycie „Pamiętnika Teatralnego” D. Jarząbek-Wasyl (przyp. red.).

${ }_{51}$ Zob. np. list Osterwy do Lutosławskiego z 1943, Muzeum Teatralne w Warszawie, sygn. D. 850 a III.

${ }_{52}$ I. Lutosławska-Wolikowska, Roman Dmowski (3) „Do niepodległości wytrwam”, „Myśl Polska" $1956 \mathrm{nr} 7$ (1 IV), http://mbc.cyfrowemazowsze.pl/dlibra/docmetadata?id=53900\&from=publication [dostęp: 22 VI 2020]. Zob. też I. Lutosławska-Wolikowska, Roman Dmowski: człowiek, Polak, przyjaciel, Chicago 1961. Siostra Izabelli, Maria, i jej mąż Konrad Niklewicz, chrześniak Dmowskiego, opiekowali się nim w ostatnich latach jego życia, aż do śmierci.

${ }_{53}$ Zob. T. Bielecki, W szkole Dmowskiego, Londyn 1968, s. 60. 
łamach endeckich gazet. W tym okresie jego córka Izabella w „Gazecie Warszawskiej” drukowała powieść w odcinkach Bolszewicy w polskim dworze - opartą na osobistych wspomnieniach, ale i nawiązującą niejako do epilogu dramatu Żeromskiego. Wpływ znajomości z Dmowskim na Lutosławską jest niewątpliwy. Czy jednak był też tak silny w przypadku jej ojca?

W archiwum Osterwy zachowała się broszura, w której Lutosławski w 1937 pisał, że „Polska ma prawo żądać od Europy co najmniej granic 1772 r. - z dodatkiem Gdańska, Prus Wschodnich, Śląska Opolskiego i Śląska Cieszyńskiego całego". Proponował też unię z Czechami, Węgrami, Rumunią:

To państwo od Dunaju i Morza Czarnego do zatoki finlandzkiej powinno mieć jednolite wojsko, flotę i lotnictwo dla obrony przed Moskwą i Niemcami. Estończycy, Łotysze, Litwini, Białorusini, Rusini, Rumuni, Czesi, Słowacy, Węgrzy powinni w ścisłym związku z Polską wytworzyć jedno państwo, w którym każdy lud będzie miał najdalej idącą swobodę kulturalnego rozwoju, a wszystkie razem będą się między sobą porozumiewać po polsku we wspólnym wojsku i wspólnym parlamencie. W tym państwie każdy obywatel będzie miał otwartą drogę do najwyższych urzędów - i Polacy nie będą pod żadnym względem uprzywilejowani. Stolicą Wielkiej Polski stworzonej przez powyższe dziesięć ludów, powinien zostać Kraków ${ }^{54}$.

Widać w tym tekście splot idei Dmowskiego i Piłsudskiego: endecka idea Wielkiej Polski została skrzyżowana z federacyjną wizją Trójmorza Piłsudskiego. Wydaje się, że w podobny sposób te dwa główne nurty ideologiczne II Rzeczypospolitej postrzegał również Osterwa, który artykuł Lutosławskiego przechowywał. Ciąg dalszy broszury dokładniej wyjaśnia zarówno fascynację, jak i ostateczne zniechęcenie Lutosławskiego ${ }^{55}$ do obu przywódców politycznych w Polsce okresu międzywojennego. Równocześnie filozof podkreśla, że wychował dla endecji wielu swoich uczniów.

${ }^{54}$ W. Lutosławski, Główne prawdy, „Lotos” $1937 \mathrm{nr}$ 2, 3, 4 , zob. też: https://sbc.org.pl/dlibra/ publication/17234/edition/15050 [dostęp: 22 VI 2020].

55 Ibidem. O Dmowskim: „W polityce byłem zawsze republikaninem i przeciwnikiem praw dynastycznych. Gdym osiadł w Krakowie w 1900 r. zostałem przyjęty do Ligi Narodowej przez Zygmunta Balickiego i na jego zlecenie przeprowadziłem w Poznaniu pierwszy zaczątek tajnej organizacji narodowej [...]. Ale w miarę jak bliżej poznałem Romana Dmowskiego i przekonałem się o jego indyferentyzmie religijnym, o niesłychanej jego ignorancji filozoficznej, oraz o braku jakichkolwiek stałych przekonań metafizycznych, zacząłem się oddalać od endecji. Jednak endecja mnie zawdzięcza udział w niej moich braci i wielu moich uczni [!]. Dopiero w czasie wojny w Paryżu, gdy Dmowski i Haller wyłącznie opanowali tworzące się niezależnie od nich polskie wojsko - straciłem zupełnie zaufanie do tego kierunku, który przez kilkanaście lat popierałem. Odtąd z coraz to większą stanowczością zwalczałem wszelkie stronnictwa i żądałem jedności narodowej w licznych moich wykładach w blisko 200 miastach Polski” (s. 3). O Piłsudskim: „Gdy osobiście poznałem Piłsudskiego, miałem do niego wyraźną sympatię i rozumiałem jego przewagę nad Dmowskim. Ale przesadne hołdy pośmiertne zachwiały moim zaufaniem do trwałego znaczenia jego wpływu. Ta fikcja nadludzkiego bohatera wydała mi się większym fałszem, niż romantyczna miłość kobiety lub tajemna wiedza okultysty” (s. 5). 
Biograficzne informacje o kręgach intelektualnych, w jakich obracał się Osterwa, w połączeniu z oczekiwaniem środowiska prawicowego na nowy teatr i jego akceptacją dla twórcy Reduty w początkowym okresie jej działalności pozwalają dopatrywać się związków Juliusza Osterwy z myślą narodową. Teatr, który tworzył, miał być narzędziem na froncie walki o polską kulturę. Jego rola miała nie ograniczać się do rozwijania czy propagowania rodzimego repertuaru i poszukiwania dla niego oryginalnej, nowoczesnej formy. Nowy teatr Osterwy miał być również nośnikiem patriotycznej, pełnej poświęcenia postawy. 


\section{ANEKS}

\section{OBRAZ ŻYCIA TEATRALNEGO W WARSZAWIE W 1920 WEDŁUG „GAZETY WARSZAWSKIEJ”}

Miesiąc przed decydującą bitwą w wojnie polsko-bolszewickiej w Warszawie grano tzw. normalny repertuar ${ }^{56}$, chociaż zaczęły pojawiać się również premiery sformatowane pod nową sytuację. Pokazują to „znaczące” tytuły, np. Teatr Praski wystawia Nad przepaścia i Kilińskiego, Teatr Powszechny wychodzi z przedstawieniem Polakożercy, a Teatr Żołnierski gra Zaręczyny pod kulami. Poziom tych premier jednak znacznie się różni od Ponad śnieg Żeromskiego w Reducie, a recenzenci „Gazety Warszawskiej” przywiązują wagę do formy i artystycznego poziomu przedstawień. Podjęcie patriotycznego tematu nie zwalniało w ich opinii z powinności artystycznych, co widać choćby w recenzji Polakożerców:

Zachęcony powodzeniem „Tamtego” G. Zapolskiej oraz innych sztuk „patriotycznych” p. Swoboda-Trzebiński napisał dramat „Polakożercy”. Ponieważ p. Trzebiński jest kierownikiem artystycznym Teatru Powszechnego, więc oczywiście zakwalifikował utwór swój do grania na tej scenie. Podług błędnej teorii p. Trzebińskiego, aby osiągnąć sukces dramaturga, dość jest poubierać artystów w żandarmerskie mundury, kazać różnym Żuczkowym, Czihanowym i Poliwantowym popełniać masę podłości, włożyć wreszcie w usta kilku osób szereg oklepanych zdań patriotycznych. A talent, a nerw sceniczny czy są potrzebne? Autor „Polakożerców” sądzi iż nie, dlatego dał nam rzecz bardzo naiwną i słabą. Artyści robili, co mogli, aby sztukę od krachu ocalić. Dobrą grą wyróżnili się pp. Puchalski, Wacławski, Wandycz oraz Staniewski. P. Biernacka fatalną grą zepsuła rolę nieszczęśliwej Rzepeckiej: zamiast łzy wyciskać ta ofiara żandarmów pobudzała widzów do śmiechu. Pomimo starannej wystawy, chybiona sztuka nie podobała się publiczności ${ }^{57}$.

Z lepszym przyjęciem spotkała się sierpniowa premiera Teatru Powszechnego, który nie zniechęcił się krytyką i dał „dramat patriotyczny” Leopolda Starzeńskiego Gwiazda Syberii:

Aczkolwiek sztuka ta nie posiada wielkiej wartości scenicznej, jednakże ma ona szczęście do szerokiego ogółu publiczności, i dlatego grywana jest chętnie przez teatry polskie.

„Gwiazda Syberii” to obraz męczeństwa ojców i dziadów naszych, to wyrok potępienia wydany

${ }^{56}$ Stan repertuaru warszawskiego na dzień 30 VII 1920: Teatr Pomarańczarnia Panna mężatka, Teatr Polski Klub kawalerów, Teatr Mały Aszantka, Teatr Reduta Papierowy kochanek, Teatr Nowości Księżna Czardaszka, Królowa Kinematografu, Teatr Bagatela Dobrze skrojony frak, Teatr Praski Córka putku, Teatr Powszechny Polakożercy.

57 Z Teatru Powszechnego, „Gazeta Warszawska” 1920 nr 204 (28 VII), https://polona.pl/item/gazetawarszawska-r-140-nr-204-28-lipca-1920,MTEzNjg2MDE0/2/\#info:metadata [dostęp: 22 VI 2020]. 
na nieludzkich carów moskiewskich oraz ich nędznych pachołków, znęcających się nad bohaterami nieszczęsnego narodu, co wolność postradał. [...] Artyści lubią grywać „Gwiazdę Syberii” widząc, że nastrój tej sztuki znajduje wdzięczne echo w sercach słuchaczów. Wykonanie na ogół było bardzo dobre. Najlepszym był kniaź Anzelm w kreacji p. Wacławskiego. Rolę intryganta - majora odegrał bardzo dobrze p. Staniewski. Pani Szpakowskiej w roli tytułowej brakowało w niektórych scenach siły dramatycznej. Pan Dębicz dobrze odtwarzał Kazimierza, tylko chwilami szedł zbytecznym patosem. Poprawnym komendantem był p. Puchalski. Wystawa bardzo staranna. Sztukę przyjmowano hucznymi oklaskami ${ }^{58}$.

Pojawiły się też w Warszawie teatry żołnierskie. Dokładnie w dniach bitwy warszawskiej grał Teatr Żołnierski przy dowódcy frontu północnego, dający przedstawienia na rzecz pożyczki odrodzenia. Występował w sali Stowarzyszenia Robotników Chrześcijańskich przy ulicy Kaliksta (później Śniadeckich) z programem składającym się z produkcji muzycznych popularnej orkiestry Namysłowskiego oraz z popisów znanych artystów-żołnierzy: Stefana Szoslanda, Henryka Rydzewskiego, Wacława Janoty-Jarzębskiego, Mieczysława Zonera, Czesława Muraszkiewicza, Józefa Ciesielskiego, Wacław Malinowskiego, Cecylii Horowiczowej i Ciesielskiej. Wykonywali ,pieśni aktualne, piosenki żołnierskie, tańce, monologi, satyry”, ale też ,szkic aktualny” Łazik w interpretacji porucznika Przyborowskiego ${ }^{59}$.

Ten sam Teatr Żołnierski wystąpił po raz kolejny w Warszawie już po kryzysie wojennym, we wrześniu, gdy walki jeszcze trwały, jednak apogeum wojny już minęło. Wojskowa i cywilna publiczność stale wypełniała po brzegi obszerną salę przy ul. Śniadeckich. Na czele teatru stał Michał Orlicz w randze porucznika, znany już w tym czasie krytyk, z doświadczeniem nabytym w Monachium i Paryżu. W kierownictwie owego teatru pojawił się też inny krytyk i teatrolog - Eugeniusz Świerczewski ${ }^{60}$.

Nadal grała zmilitaryzowana orkiestra Namysłowskiego, której członkowie wraz z kierownikiem „w chwili grożącego Ojczyźnie niebezpieczeństwa, bez wyjątku do swych barwnych strojów ludowych przypięli biało-amarantowe kokardy ochotnicze”. Program ten sam co w sierpniu:

W dziale kabaretowym wystąpił p. Muraszkiewicz, z szeregiem patriotycznych deklamacji, p. Janota targał za serca piosenkami żołnierskimi, p. Zonner komicznym monologiem śmieszył do łez, a p. Szotland był wybornym łobuzem warszawskim. Wszystkich porwał taniec p. Ciesielskiego z ogromną werwą wykonany, p. Rydzewski, chociaż nieco niedomagający, z powodzeniem odśpiewał kilka ładnych piosenek. Na zakończenie odegrano doskonałą, agitacyjną

58 Z Teatru Powszechnego, „Gazeta Warszawska” 1920 nr 222 (15 VIII), https://polona.pl/item/ gazeta-warszawska-1920-nr-239-r-140-nr-239-1-wrzesnia-1920,NzU3NzM5Mg/3/\#info:metadata [dostęp: 22 VI 2020].

59 Zob. Teatr Żolnierski, „Gazeta Warszawska” 24 VIII 1920 nr 231 (24 VIII), https://polona.pl/ item/gazeta-warszawska-r-140-nr-231-24-sierpnia-1920,NzU3NzI4Mg/2/\#info:metadata [dostęp: 22 VI 2020].

${ }^{60}$ Por. Piśmiennictwo i sztuka. Z Teatru Żotnierskiego, „Gazeta Warszawska” 1920 nr 239 (1 IX), https://polona.pl/item/gazeta-warszawska-1920-nr-239-r-140-nr-239-1-wrzesnia-1920,NzU3NzM5Mg/3/\#info:metadata [dostęp: 22 VI 2020]; zob. też: M. Wosiek, op. cit. 
jednoaktówkę por. Przyborowskiego Łazik pełną ruchu i humoru. Oprócz wyżej wymienionych artystów brały w niej udział panie Horowiczowa i Ciesielska. Powodzenie było na całym froncie. Dochód czysty przeznaczony na rzecz skarbu ${ }^{61}$.

We wrześniu teatr rozszerzył swój repertuar o „wesołą jednoaktówkę” Stefana Kiedrzyńskiego Zaręczyny pod kulami ${ }^{62}$.

W Teatrze Powszechnym również zapanował lżejszy nastrój: temat wojny podjęto tym razem za pośrednictwem farsy francuskiej Hennequina i Vebera Chrześniak wojenny. „Obecny tydzień w teatrze na Lesznie nazwać można «tygodniem śmiechu» [...] Co wieczór widzowie zaśmiewają się na pysznej farsie francuskiej”. Bohaterem zawikłanej fabuły jest ,,szofer wojskowy”, który „zdradził młodą żoneczkę przez «patriotyzm», ponieważ zagalopował się z osóbką, którą przejechał samochodem, a która groziła skandalem całej armii”. Inscenizacja miała jednak pewien aspekt zbliżający ją do tego, co dziś nazywamy teatrem krytycznym, wskazuje na to uwaga recenzenta: „Zapytajmy reżysera: skąd na ścianach mieszkania Francuza wzięły się portrety Kościuszki, Ks. Józefa, Mickiewicza i Słowackiego?"63

Także we wrześniu 1920 zaczął w Warszawie występować, nie gościnnie, lecz regularnie, Teatr Wojskowy Y.M.C.A. Siedzibę znalazł przy ulicy Oboźnej 1/3, czyli w rotundzie na Dynasach, nieopodal Teatru Polskiego. Grał „fascynującą sztukę” Tajemniczy Dżems, w reżyserii Antoniego Thiela. W przerwach, pomiędzy aktami, dyrektor teatru, Karol Knake-Karliński, przeprowadził coś w rodzaju pogadanki na temat: „Obowiązki żołnierza względem społeczeństwa" ${ }^{64}$. Wejście na całą imprezę było bezpłatne, przeznaczone jednak wyłącznie dla wojskowych.

${ }^{61}$ Z Teatru Żotnierskiego, „Gazeta Warszawska” 1920 nr 239 (1 IX), https://polona.pl/item/ gazeta-warszawska-1920-nr-239-r-140-nr-239-1-wrzesnia-1920,NzU3NzM5Mg/3/\#info:metadata [dostęp: 22 VI 2020].

${ }_{62}$ Teatr wojskowy, „Gazeta Warszawska” $1920 \mathrm{nr} 250$ (12 IX) (zob. link w przyp. 60).

${ }^{63}$ Z Teatru Powszechnego, „Gazeta Warszawska” 1920 nr 242 (4 IX), https://polona.pl/item/gazeta-warszawska-r-140-nr-242-4-wrzesnia-1920,NzU3NzQzMw/3/\#info:metadata [dostęp: 22 VI 2020]. W sztuce grali: S. Dębicz, S. Staniewski, W. Puchalski, J. Brzozowska i S. Szpakowska.

${ }^{64}$ Y.M.C.A Teatr żotnierza polskiego, „Gazeta Warszawska” $1920 \mathrm{nr} 254$ (16 IX) https://polona. pl/item/gazeta-warszawska-r-140-nr-254-16-wrzesnia-1920,NzU3NzUyOQ/1/\#info:metadata [dostęp: 22 VI 2020]. W sztuce grali: Z. Sokołowicz, Stanisławska, Bogdanowicz, Kalinowski, Leski, M. Rembosz, A. Thiel, K. Wyrwicz-Wichrowski. Z biogramu Knake-Karlińskiego wynika, że jego teatr, działający przez 18 miesięcy od IX 1919 do XII 1920, występował także na froncie, bo w Równem, Żytomierzu i Kijowie, http://www.encyklopediateatru.pl/osoby/26522/karol-karlinski [dostęp: 22 VI 2020]. 